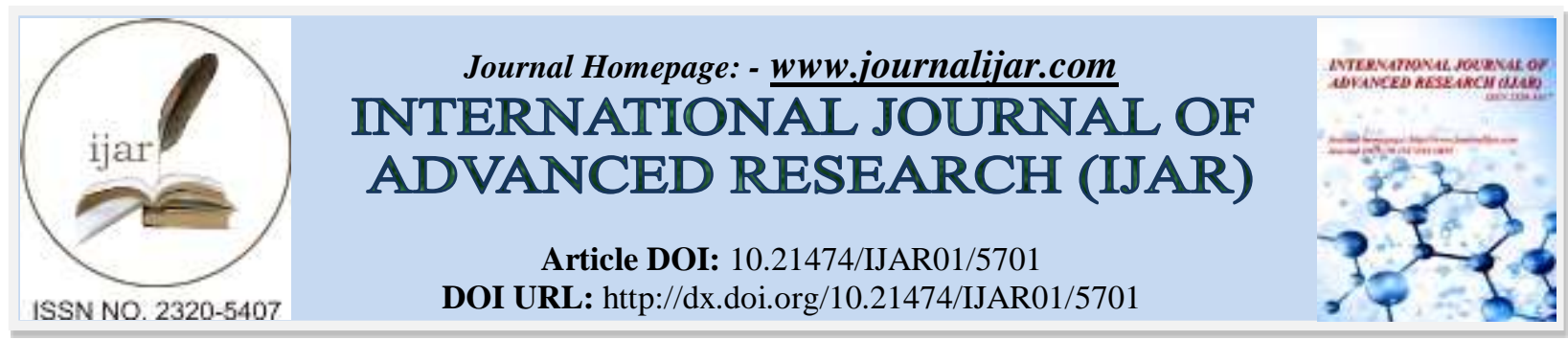

RESEARCH ARTICLE

\title{
LEVEL OF PERFORMANCE OF HEADS OF AGENCIES/DEPARTMENTS IN SELECTED PUBLIC AND PRIVATE INSTITUTIONS IN THE PROVINCE OF LAGUNA.
}

Daisy L. Aranguren. Ed. D.

Research and Development Unit Head College of Teachers Education, LAGUNA STATE POLYTECHNIC UNIVERSITY SAN PABLO CITY CAMPUS Brgy. Del Remedio, San Pablo City, Laguna Philippines 4000.

\section{Manuscript Info}

Manuscript History

Received: 23 August 2017

Final Accepted: 25 September 2017

Published: October 2017

\section{Abstract}

The study focused on the level of performance of public and private managers in selected offices/agencies in the Province of Laguna, Philippines.

It sought answer to the respondents perceived level of performance of the managers in public and private sectors in terms of planning and organizing work, utilization and management of resources, promptness in submission of reports, problem analysis and decision - making, leadership and personnel management, and public relations and community involvement.

The significant difference in the perception of the respondents on the level of performance of the managers/head of offices/agencies /departments from the public and private sectors and the relationship of the job related factors as time management, attitudes towards job, working condition and relationship with subordinates to the level of performance of the manager respondents.

Descriptive and inferential statistical techniques were utilized to analyze and interpreted the gathered data. For the description of the profile of the respondents, frequency distribution, percentage and ranking were used.

The $\mathrm{t}$ - test for independent samples determined the significant differences between the perceptions of the managers and the subordinates with regards to the level of performance of the managers. Pearson - Product Moment Coefficient of Correlation was used to determine the relationship between the level of performance of the managers and the extent of adequacy of the job related factors at a significance level of .05.

As to the findings of the study, the perceived level of performance of heads of agencies/departments in selected public and private institutions in the Province of Laguna, Philippines was found "Very Effective' in terms of planning and organizing, utilization and management of resources, promptness in submission of reports, problem analysis and decision making, leadership and personnel management, public relations and community involvement.

Copy Right, IJAR, 2017,. All rights reserved. 


\section{Introduction:-}

According to McFarland, the decision by which managers creates or maintain an organization structure are among the most critical that he makes. The problem is a continuous one, since internal and external forces are constantly having an impact on the existing structure, producing dynamic changes. The process of planning, setting objectives, and problem solving are inextricably linked with problems on organization design. Organization design is also important because of the impact of structure on the behavior and attitudes of the organization members whose performances are directly related to the effectiveness and efficiency of the system.

Considering today's complex problems of administration and supervision, it is imperative that executives in key positions within an organization should have a keen understanding of the dynamic factors that influence the performance of those under their leadership. It is within the premise that this study was undertaken.

\section{Statement of the Problems:-}

This study aimed to determine the influence of certain personal and job related factors to the level of performance of heads of agencies/departments in selected public and private institution in the Province of Laguna.

Specifically, it sought to answer the following questions:

What is the profile of the respondents based on:

1. Age

2. Sex

3. Civil Status/

4. Status of Appointment

5. Position

6. Highest Educational Attainment

7. Length of Service

8. Level of Awards Received

9. Nature of Job

10. Monthly Salary

11. Rate of Promotion

How do the respondents perceived the level of performance of the managers/heads of offices in public and private sectors in terms of:

1. Planning and Organizing Work

2. Utilization and Management of Resources

3. Promptness in Submission of Required Reports

4. Problem Analysis and Decision- Making

5. Leadership and Personnel Management

6. Public Relation and Community Involvement

Is there a significant difference between the perceptions of respondents on the level of performance of heads of Agencies/departments from the public and private sectors?

Do the following job related factors have relationship with the level of performance of the manager respondents?

1. Time Management

2. Attitudes Towards Job

3. Working Conditions

4. Relationship with Subordinates

5. What are the problems encountered by the respondents relative to their jobs?

\section{Methodology:-}

This research attempted to determine the relationship between the level of performance of the heads of agencies/offices as indicated by the management functions of planning and organizing, utilization and management of resources, promptness in submission of reports, problem analysis and decision- making, leadership and personnel management and public relations and community involvement certain personal factors in terms of age, sex, civil status, status of appointment, position, educational attainment, length of service, awards received, nature of job, 
monthly salary and rate of promotion and the job related factors with regards to time management, attitude towards job, working conditions and relationship with subordinates.

The descriptive research design was used to conduct the study using fifty (50) heads of offices/managers and fifty (50) subordinates for each group of respondents as purposive samples from nine (9) public offices and seven (7) private agencies in the province of Laguna.

There were two sets of questionnaires used in the study. One set for the managers and another set for the subordinates. The research instrument for the managers elicited personal information and their perceptions on the adequacy of the job-related factors. Likewise, the questionnaire for the subordinates also gathered personal information and their perceptions on the level of performance of their managers. The responses of the managers and subordinates which represented the data were grouped, tabulated, and coded for interpretation and analysis.

\section{Findings:-}

The following are the salient findings of the study.

Profile of the Respondents

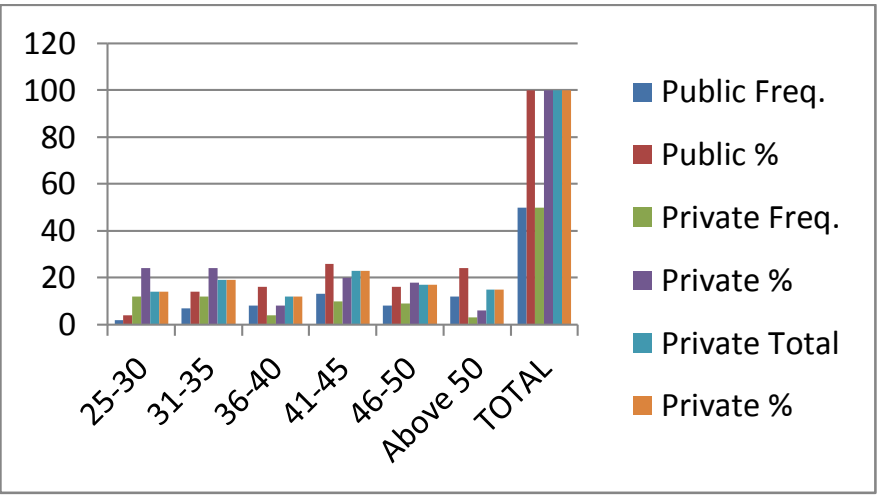

Table 1:- Distribution of Managers as to Age

\begin{tabular}{|l|l|l|l|l|l|l|}
\hline & Public & Private & & \\
\hline & Freq. & $\%$ & Freq. & $\%$ & Total & $\%$ \\
\hline $25-30$ & 2 & 4 & 12 & 24 & 14 & 14 \\
\hline $31-35$ & 7 & 14 & 12 & 24 & 19 & 19 \\
\hline $36-40$ & 8 & 16 & 4 & 8 & 12 & 12 \\
\hline $41-45$ & 13 & 26 & 10 & 20 & 23 & 23 \\
\hline $46-50$ & 8 & 16 & 9 & 18 & 17 & 17 \\
\hline Above 50 & 12 & 24 & 3 & 6 & 15 & 15 \\
\hline TOTAL & 50 & 100 & 50 & 100 & 100 & 100 \\
\hline
\end{tabular}

Table 2:- Distribution of Subordinates as to Age

\begin{tabular}{|l|l|l|l|l|l|l|}
\hline Age & Public & Private & \multicolumn{2}{l|}{} \\
\hline & Freq. & $\%$ & Freq. & $\%$ & Total & $\%$ \\
\hline $25-30$ & 16 & 32 & 15 & 30 & 31 & 31 \\
\hline $31-35$ & 11 & 22 & 10 & 20 & 21 & 21 \\
\hline $36-40$ & 7 & 14 & 7 & 14 & 14 & 14 \\
\hline $41-45$ & 9 & 18 & 7 & 14 & 16 & 16 \\
\hline $46-50$ & 4 & 8 & 7 & 14 & 11 & 11 \\
\hline Above 50 & 3 & 6 & 4 & 8 & 7 & 7 \\
\hline TOTAL & 50 & 100 & 50 & 100 & 100 & 100 \\
\hline
\end{tabular}




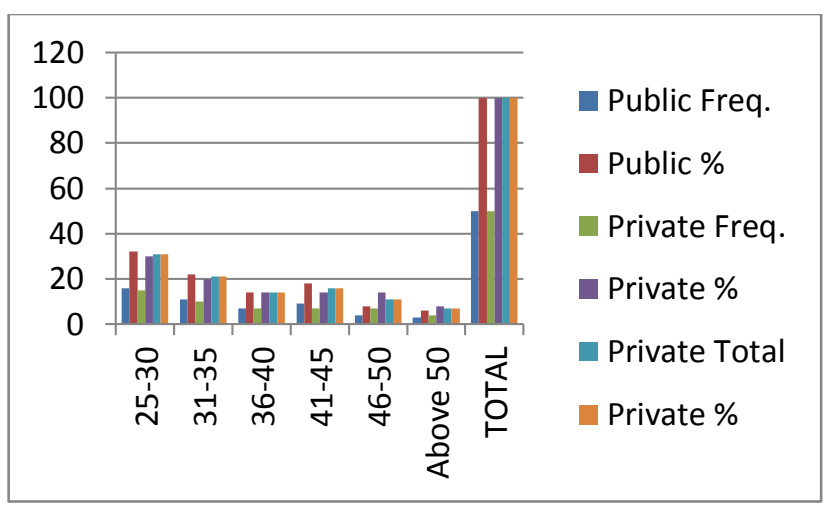

Twenty three (23\%) of public and private managers are $41-45$ years while Thirty one (31\%) of the subordinates belong to 25-30 years age bracket.

Table 3:- Distribution of Managers as to Gender

\begin{tabular}{|l|l|l|l|l|l|l|}
\hline Gender & Public & Private & \multicolumn{2}{l|}{} \\
\hline & Freq. & $\%$ & Freq. & $\%$ & Total & $\%$ \\
\hline Male & 20 & 40 & 22 & 44 & 42 & 42 \\
\hline Female & 30 & 60 & 28 & 56 & 58 & 58 \\
\hline Total & 50 & 100 & 50 & 100 & 100 & 100 \\
\hline
\end{tabular}

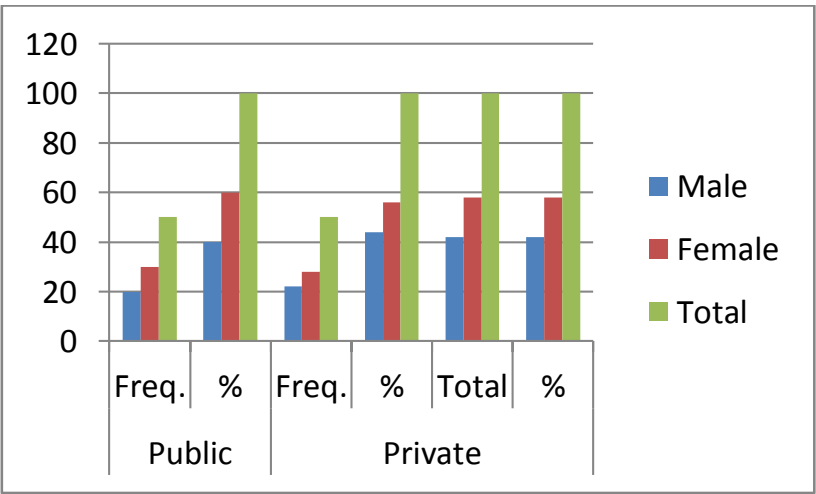

Table 4:- Distribution of Subordinates as to Gender

\begin{tabular}{|l|l|l|l|l|l|l|}
\hline Gender & Public & Private & \multicolumn{2}{l|}{} \\
\hline & Freq. & $\%$ & Freq. & $\%$ & Total & $\%$ \\
\hline Male & 21 & 42 & 22 & 44 & 43 & 43 \\
\hline Female & 29 & 58 & 28 & 56 & 57 & 57 \\
\hline Total & 50 & 100 & 50 & 100 & 100 & 100 \\
\hline
\end{tabular}

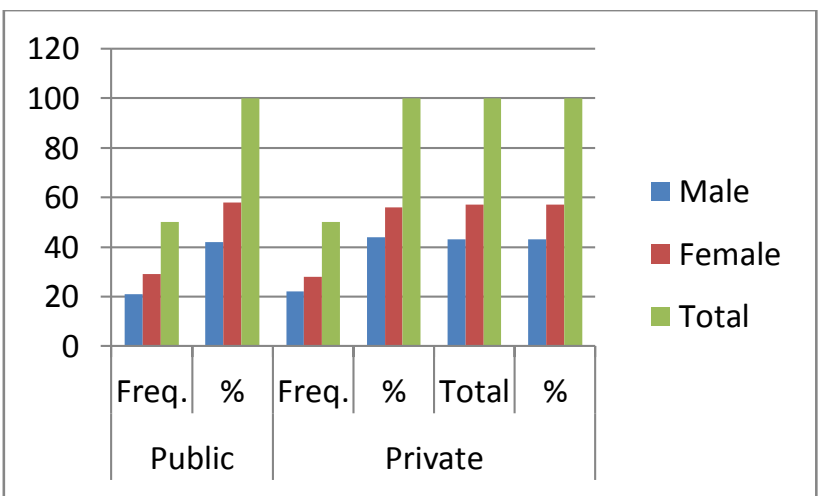


Fifty eight (58\%) are managers while fifty seven (57\%) are subordinates, majority of the managers (58\%) and subordinates $(57 \%)$ are females while $(42 \%)$ were male managers and $(43 \%)$ were male subordinates.

Table 5:- Distribution of Managers as to Civil Status.

\begin{tabular}{|l|l|l|l|l|l|l|}
\hline Civil Status & Public & Private & \multicolumn{2}{l|}{} \\
\hline & Freq. & $\%$ & Freq. & $\%$ & Total & $\%$ \\
\hline Single & 10 & 20 & 19 & 38 & 29 & 29 \\
\hline Married & 36 & 72 & 28 & 56 & 64 & 64 \\
\hline Widowed & 4 & 8 & 2 & 4 & 6 & 6 \\
\hline $\begin{array}{l}\text { Separated/ } \\
\text { Divorced }\end{array}$ & & & 1 & 2 & 1 & 1 \\
\hline TOTAL & 50 & 100 & 50 & 100 & 100 & 100 \\
\hline
\end{tabular}

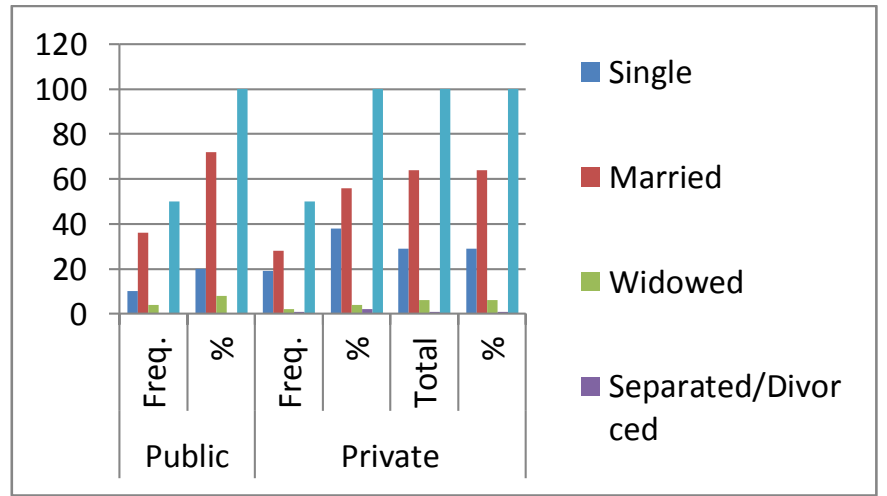

Table 6:- Distribution of Subordinates as to Civil Status

\begin{tabular}{|l|l|l|l|l|l|l|}
\hline Civil Status & Public & Private & \multicolumn{2}{l|}{} \\
\hline & Freq. & $\%$ & Freq. & $\%$ & Total & $\%$ \\
\hline Single & 32 & 64 & 20 & 40 & 52 & 52 \\
\hline Married & 10 & 20 & 14 & 28 & 24 & 24 \\
\hline Widowed & 3 & 6 & 12 & 24 & 15 & 15 \\
\hline $\begin{array}{l}\text { Separated/ } \\
\text { Divorced }\end{array}$ & 5 & 10 & 4 & 8 & 9 & 9 \\
\hline TOTAL & 50 & 100 & 50 & 100 & 100 & 100 \\
\hline
\end{tabular}

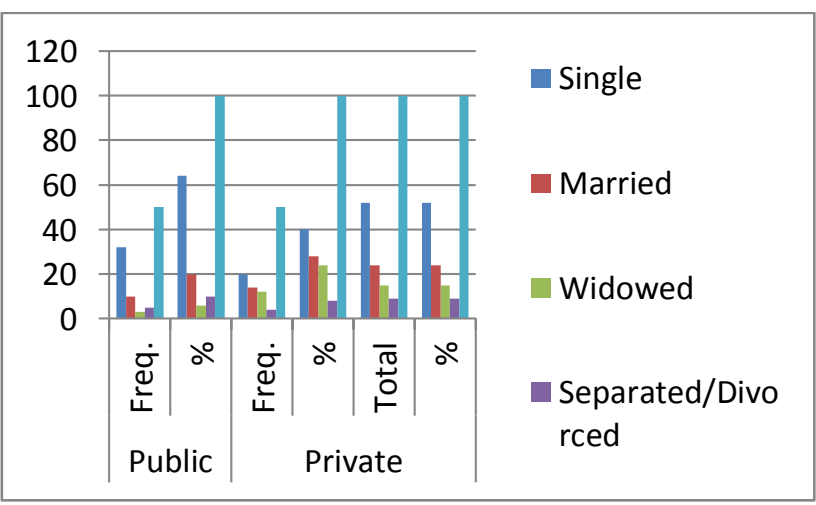

Sixty four (64\%) of the managers were married and fifty two (52\%) of the subordinates were single. 
Table 7:- Distribution of Managers as to Status of Appointment

\begin{tabular}{|l|l|l|l|l|l|l|}
\hline Status of Appointment & Public & Private & \multicolumn{2}{l|}{} \\
\hline Contractual & Freq. & $\%$ & Freq. & $\%$ & Total & $\%$ \\
\hline Probationary & 2 & 4 & 4 & 8 & 6 & 6 \\
\hline Permanent & 1 & 2 & 1 & 2 & 2 & 2 \\
\hline Total & 47 & 94 & 45 & 90 & 92 & 92 \\
\hline
\end{tabular}

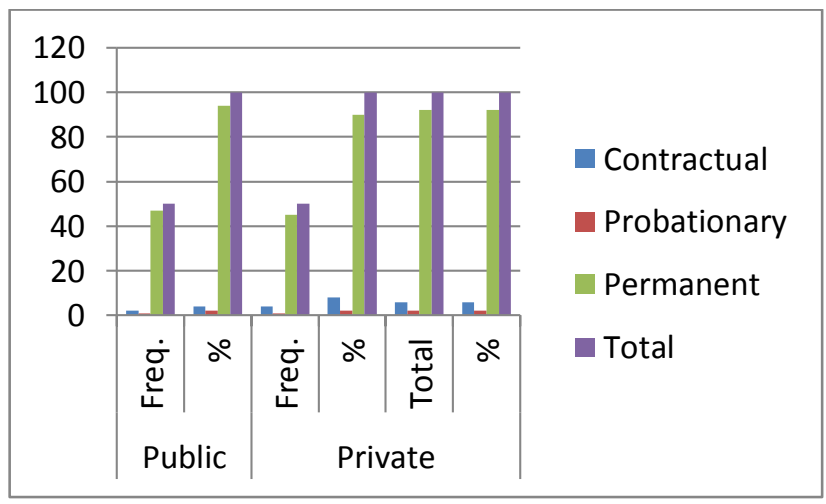

Table 8:- Distribution of Subordinates as to Status of Appointment

\begin{tabular}{|l|l|l|l|l|l|l|}
\hline Status of Appointment & Public & Private & \multicolumn{2}{l|}{} \\
\hline & Freq. & $\%$ & Freq. & $\%$ & Total & $\%$ \\
\hline Contractual & 17 & 34 & 10 & 20 & 27 & 27 \\
\hline Probationary & 3 & 6 & 22 & 44 & 25 & 25 \\
\hline Permanent & 30 & 60 & 18 & 36 & 48 & 48 \\
\hline Total & 50 & 100 & 50 & 100 & 100 & 100 \\
\hline
\end{tabular}

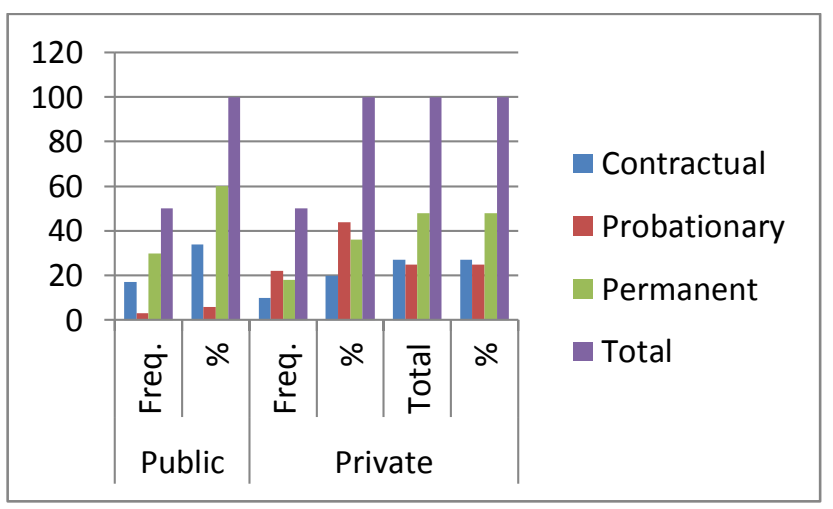

Ninety two (92\%) of the managers occupy permanent positions while forty eight (48\%) of the subordinates occupy permanent position

Table 9:- Distribution of Managers as to Position

\begin{tabular}{|l|l|l|l|l|l|l|}
\hline Position & Public & Private & \multicolumn{2}{l|}{} \\
\hline & Freq. & $\%$ & Freq. & $\%$ & Total & $\%$ \\
\hline Foreman & 5 & 10 & 1 & 2 & 6 & 6 \\
\hline Supervisor & 12 & 24 & 15 & 30 & 27 & 27 \\
\hline Adm. Officer & 3 & 6 & 6 & 12 & 9 & 9 \\
\hline Manager & 30 & 60 & 28 & 56 & 58 & 58 \\
\hline TOTAL & 50 & 100 & 50 & 100 & 100 & 100 \\
\hline
\end{tabular}




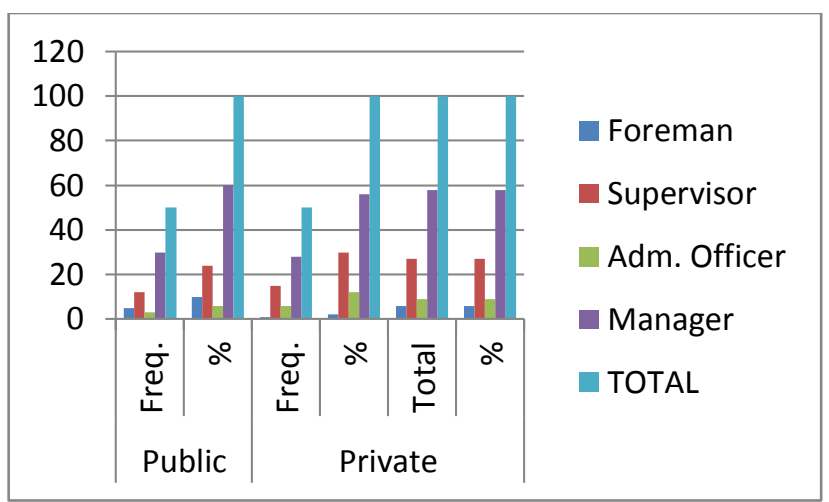

Table 10:- Distribution of Subordinates as to Position

\begin{tabular}{|l|l|l|l|l|l|l|}
\hline Position & Public & Private & \multicolumn{2}{l|}{} \\
\hline & Freq. & $\%$ & Freq. & $\%$ & Total & $\%$ \\
\hline Clerk & 20 & 40 & 14 & 28 & 34 & 34 \\
\hline Utility Worker & 10 & 20 & 10 & 20 & 20 & 20 \\
\hline Messenger & 2 & 4 & 8 & 16 & 10 & 10 \\
\hline Driver & 2 & 4 & 2 & 4 & 4 & 4 \\
\hline Technician & 1 & 2 & 5 & 10 & 6 & 6 \\
\hline Teacher & 7 & 14 & 5 & 10 & 12 & 12 \\
\hline TOTAL & 50 & 100 & 50 & 100 & 100 & 100 \\
\hline
\end{tabular}

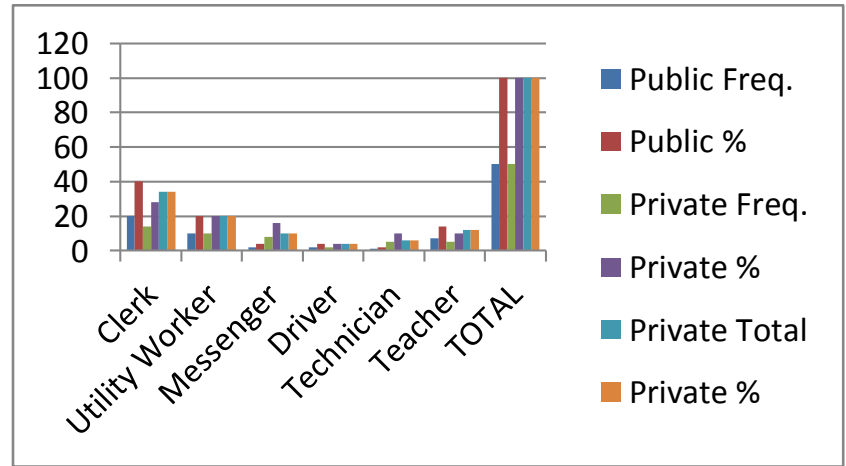

Fifty eight (58\%) of the heads of offices/agencieswere managers and (34\%) of the subordinates' works as clerk.

Table 11:- Distribution of Managers as to Educational Attainment

\begin{tabular}{|l|l|l|l|l|l|l|}
\hline Educational Attainment & Public & Private & \multicolumn{2}{l|}{$\mid$} \\
\hline & Freq. & $\%$ & Freq. & $\%$ & Total & $\%$ \\
\hline Bachelor's Degree & 6 & 12 & 25 & 50 & 31 & 31 \\
\hline $\begin{array}{l}\text { Bachelor's Degree with Masteral } \\
\text { units }\end{array}$ & 19 & 38 & 13 & 26 & 32 & 32 \\
\hline Master's Degree & 12 & 24 & 9 & 18 & 21 & 21 \\
\hline $\begin{array}{l}\text { Master's Degree with Doctoral } \\
\text { units. }\end{array}$ & 10 & 20 & 2 & 4 & 12 & 12 \\
\hline Ed.D./Ph.D & 3 & 6 & 1 & 2 & 4 & 4 \\
\hline TOTAL & 50 & 100 & 50 & 100 & 100 & 100 \\
\hline
\end{tabular}




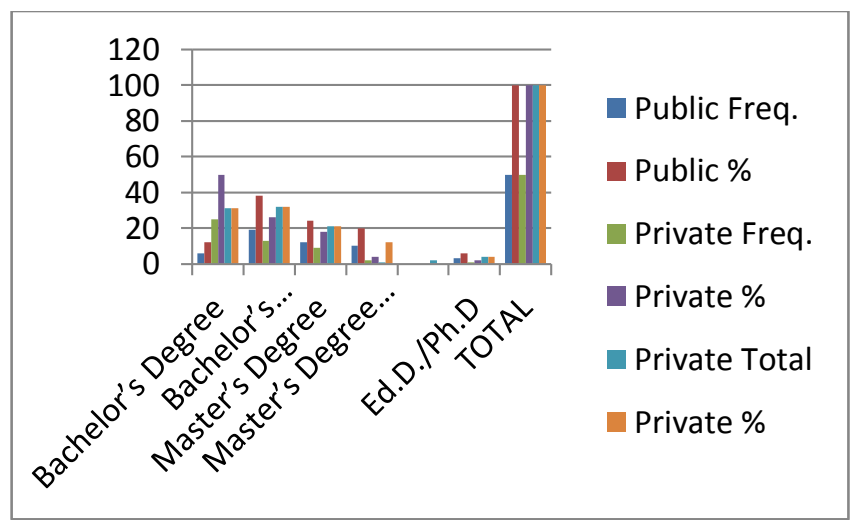

Table 12:-Distribution of Subordinates as to Educational Attainment

\begin{tabular}{|l|l|l|l|l|l|l|}
\hline Educational Attainment & Public & Private & \multicolumn{3}{l|}{} \\
\hline & Freq. & $\%$ & Freq. & $\%$ & Total & $\%$ \\
\hline $\begin{array}{l}\text { Vocational/ } \\
\text { Technician course }\end{array}$ & 12 & 24 & 15 & 30 & 27 & 27 \\
\hline Bachelor's Degrees & 25 & 50 & 20 & 40 & 45 & 45 \\
\hline $\begin{array}{l}\text { Bachelor's Degree with } \\
\text { MA Units }\end{array}$ & 13 & 26 & 15 & 30 & 28 & 28 \\
\hline TOTAL & 50 & 100 & 50 & 100 & 100 & 100 \\
\hline
\end{tabular}

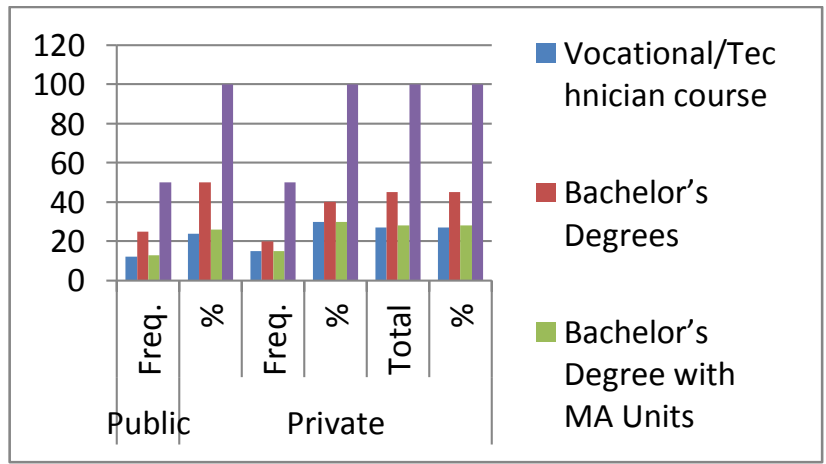

In terms of educational attainment thirty two (32\%) of the head of offices is Bachelors' Degrees with masteral units while forty $(40 \%)$ of the subordinates had finished their bachelor's degrees.

Table 13:-Distribution of Managers as to Length of Service

\begin{tabular}{|l|l|l|l|l|l|l|}
\hline Length of Service & Public & Private & \multicolumn{2}{l|}{$\mid$} \\
\hline $1-5$ years & Freq. & $\%$ & Freq. & $\%$ & Total & $\%$ \\
\hline $6-10$ years & 5 & 10 & 15 & 30 & 20 & 20 \\
\hline $11-15$ years & 8 & 16 & 11 & 22 & 19 & 19 \\
\hline $16-20$ years & 11 & 22 & 12 & 24 & 23 & 23 \\
\hline More than 20 years & 6 & 12 & 5 & 10 & 11 & 11 \\
\hline TOTAL & 20 & 40 & 7 & 14 & 27 & 27 \\
\hline
\end{tabular}




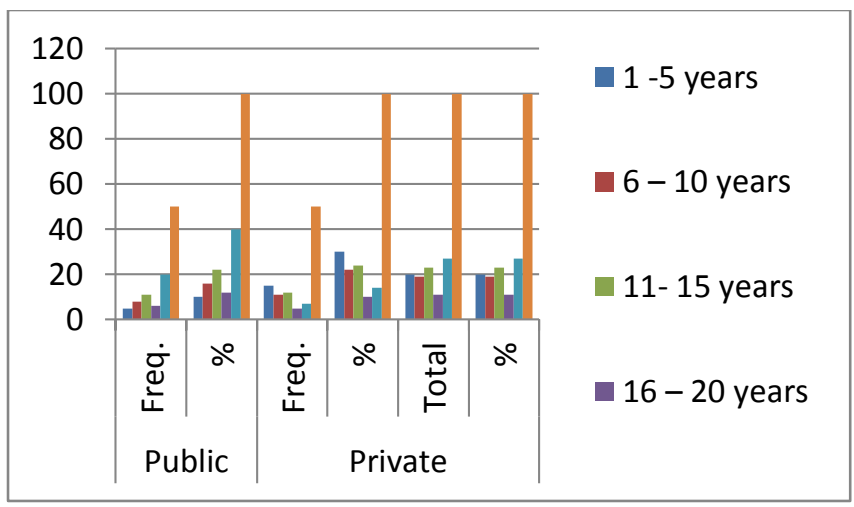

Table 14:- Distribution of Subordinates as to Length of Service

\begin{tabular}{|l|l|l|l|l|l|l|}
\hline Length of Service & Public & Private & \multicolumn{2}{|l|}{} \\
\hline & Freq. & $\%$ & Freq. & $\%$ & Total & $\%$ \\
\hline $1-5$ years & 17 & 34 & 20 & 40 & 37 & 37 \\
\hline $6-10$ years & 13 & 26 & 10 & 20 & 23 & 23 \\
\hline 15 years & 7 & 14 & 3 & 6 & 10 & 10 \\
\hline $16-20$ years & 8 & 16 & 12 & 24 & 20 & 20 \\
\hline More than 20 years & 5 & 10 & 5 & 10 & 10 & 10 \\
\hline
\end{tabular}

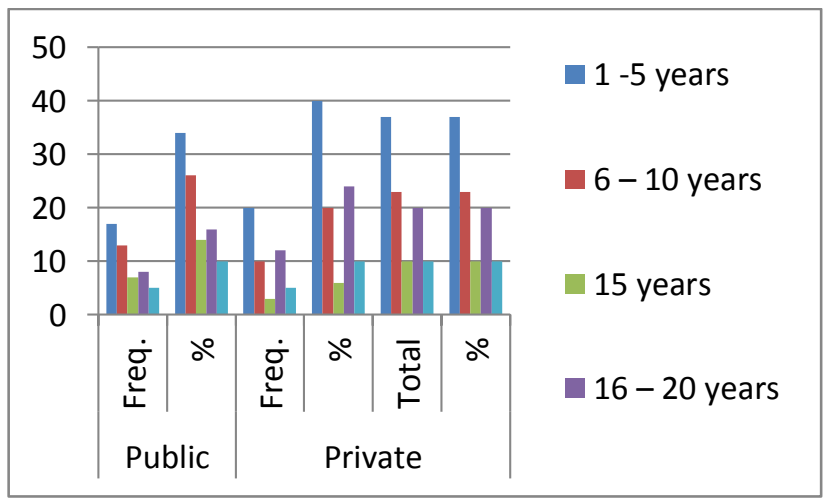

Twenty seven (27\%) of the heads of office/agency have stayed in their jobs for more than 20 years and thirty seven $(37 \%)$ of the subordinates have stayed from $1-5$ years only.

Table 15:- Distributions of Managers as to Level of Awards Received

\begin{tabular}{|l|l|l|l|l|l|l|}
\hline $\begin{array}{l}\text { Level of Awards } \\
\text { Received }\end{array}$ & Public & \multicolumn{2}{l|}{} & \multicolumn{2}{l|}{} \\
\hline & Freq. & $\%$ & Freq. & $\%$ & Total & $\%$ \\
\hline None & 28 & 56 & 32 & 64 & 60 & 60 \\
\hline Local & 10 & 20 & 8 & 16 & 18 & 18 \\
\hline Regional & 5 & 10 & 4 & 8 & 9 & 9 \\
\hline National & 7 & 14 & 6 & 12 & 13 & 13 \\
\hline TOTAL & 50 & 100 & 50 & 100 & 100 & 100 \\
\hline
\end{tabular}




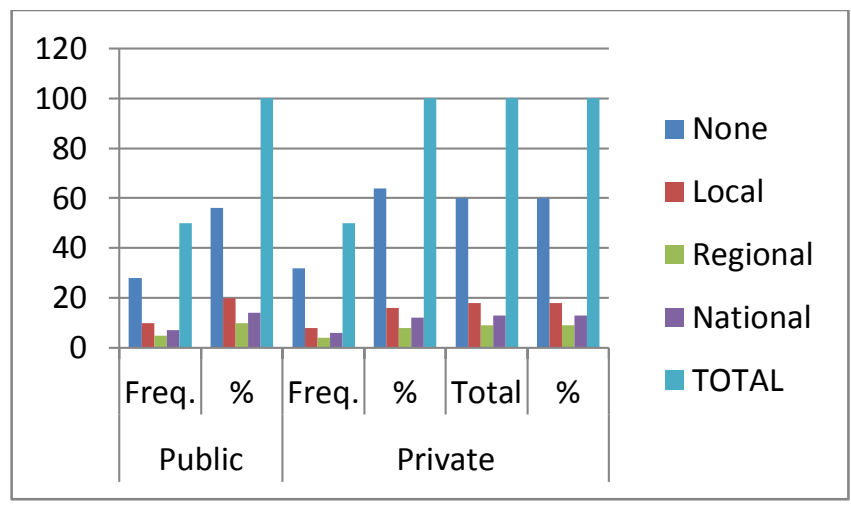

Table 16:- Distributions of Subordinates as to Level of Awards Received

\begin{tabular}{|l|l|l|l|l|l|l|}
\hline $\begin{array}{l}\text { Level of Awards } \\
\text { Received }\end{array}$ & Public & \multicolumn{2}{l|}{ Private } & \multicolumn{2}{l|}{} \\
\hline & Freq. & $\%$ & Freq. & $\%$ & Total & $\%$ \\
\hline None & 24 & 48 & 27 & 54 & 51 & 51 \\
\hline Local & 21 & 42 & 15 & 30 & 36 & 36 \\
\hline Regional & 5 & 10 & 6 & 12 & 11 & 11 \\
\hline National & 0 & 0 & 2 & 4 & 2 & 2 \\
\hline TOTAL & 50 & 100 & 50 & 100 & 100 & 100 \\
\hline
\end{tabular}

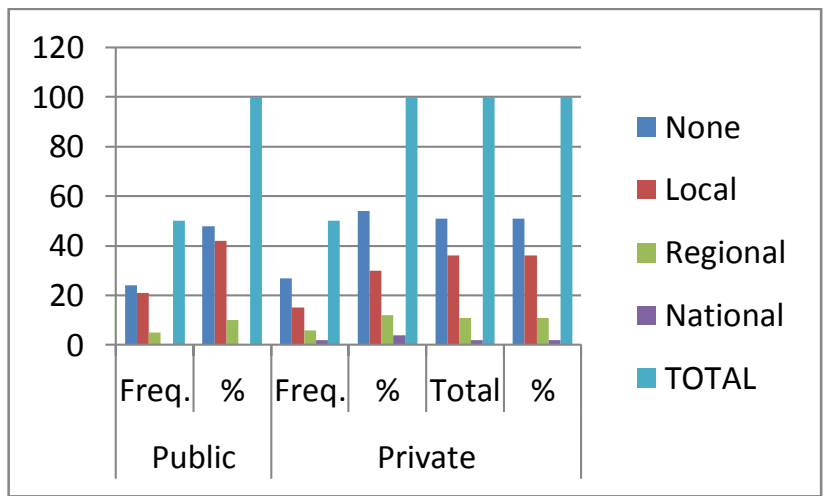

Sixty (60\%) from the public and private managers received an awards while fifty one (51\%) of the subordinates have not received any award at all.

Table 17:- Distribution of Managers as to Nature of Job

\begin{tabular}{|l|l|l|l|l|l|l|}
\hline Nature of Job & Public & Private & \multicolumn{2}{l|}{$\mid$} \\
\hline & Freq. & $\%$ & Freq. & $\%$ & Total & $\%$ \\
\hline Technical & 2 & 4 & 0 & 0 & 2 & 2 \\
\hline Extension & 3 & 6 & 1 & 2 & 4 & 4 \\
\hline Research & 6 & 12 & 3 & 6 & 9 & 9 \\
\hline Supervisory & 29 & 58 & 34 & 68 & 63 & 63 \\
\hline Managerial & 10 & 20 & 12 & 24 & 22 & 22 \\
\hline TOTAL & 50 & 100 & 50 & 100 & 100 & 100 \\
\hline
\end{tabular}




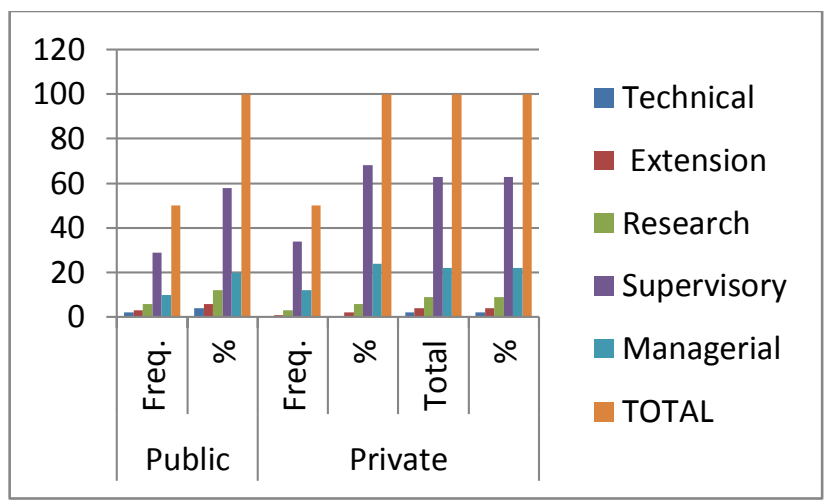

Table 18:- Distribution of Subordinates as to Nature of Job

\begin{tabular}{|l|l|l|l|l|l|l|}
\hline Nature of Job & Public & Private & \multicolumn{2}{l|}{} \\
\hline & Freq. & $\%$ & Freq. & $\%$ & Total & $\%$ \\
\hline Clerical & 13 & 26 & 12 & 24 & 25 & 25 \\
\hline Technical & 8 & 16 & 3 & 6 & 11 & 11 \\
\hline Teaching & 11 & 22 & 7 & 14 & 18 & 18 \\
\hline Auditing & 6 & 12 & 7 & 14 & 13 & 13 \\
\hline Accounting & 5 & 10 & 8 & 16 & 13 & 13 \\
\hline Research & 3 & 6 & 6 & 12 & 9 & 3 \\
\hline Extension & 4 & 8 & 7 & 14 & 11 & 11 \\
\hline TOTAL & 50 & 100 & 50 & 100 & 100 & 100 \\
\hline
\end{tabular}

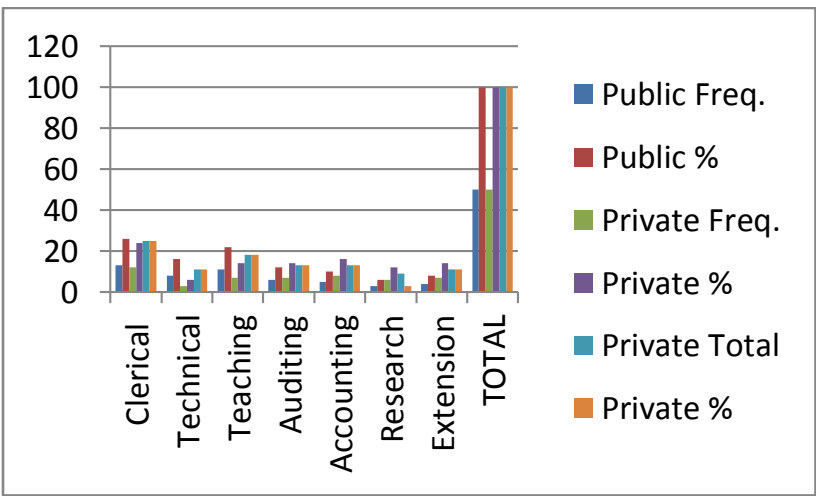

Sixty eight (68\%) of the respondents as head of offices/agencies perform supervisory functions while twenty five $(25 \%)$ of the subordinates work as clerks.

Table 19:- Distribution of Manager as to Monthly Salary

\begin{tabular}{|l|l|l|l|l|l|l|}
\hline Monthly Salary & Public & Private & \multicolumn{2}{l|}{} \\
\hline & Freq. & $\%$ & Freq. & $\%$ & Total & $\%$ \\
\hline Less than 10,000 & 5 & 10 & 12 & 24 & 17 & 17 \\
\hline $\begin{array}{l}\text { Php 10,000- } \\
15.000\end{array}$ & 22 & 44 & 17 & 34 & 39 & 39 \\
\hline $\begin{array}{l}\text { Php 16,000- } \\
20,000\end{array}$ & 17 & 34 & 7 & 14 & 24 & 24 \\
\hline $\begin{array}{l}\text { Php 21,000- } \\
25,000\end{array}$ & 6 & 12 & 1 & 2 & 7 & 7 \\
\hline $\begin{array}{l}\text { Php 26,000- } \\
30,000\end{array}$ & 0 & 0 & 1 & 2 & 1 & 1 \\
\hline More than 30,000 & 0 & 0 & 12 & 24 & 12 & 12 \\
\hline TOTAL & 50 & 100 & 50 & 100 & 100 & 100 \\
\hline
\end{tabular}




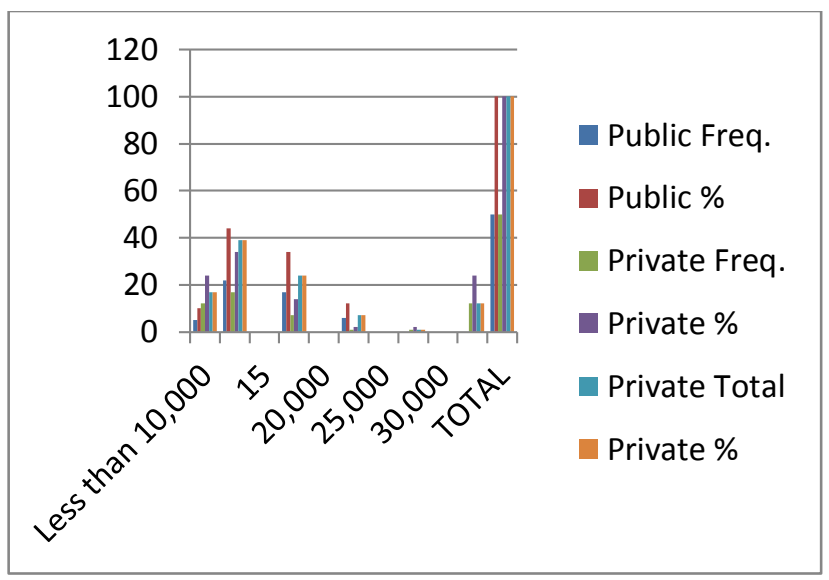

Table 20:-Distribution of Subordinates as to Monthly Salary

\begin{tabular}{|c|c|c|c|c|c|c|}
\hline Monthly Salary & \multicolumn{2}{|c|}{ Public } & \multicolumn{2}{|c|}{ Private } & & \\
\hline & Freq. & $\%$ & Freq. & $\%$ & Total & $\%$ \\
\hline Less than 10,000 & 28 & 56 & 11 & 22 & 39 & 39 \\
\hline $\begin{array}{l}\text { Php 10,000 } \\
15.000\end{array}$ & 20 & 40 & 31 & 62 & 51 & 51 \\
\hline $\begin{array}{l}\text { Php 16,000- } \\
20,000\end{array}$ & 2 & 4 & 8 & 16 & 10 & 10 \\
\hline TOTAL & 50 & 100 & 50 & 100 & 100 & 100 \\
\hline
\end{tabular}

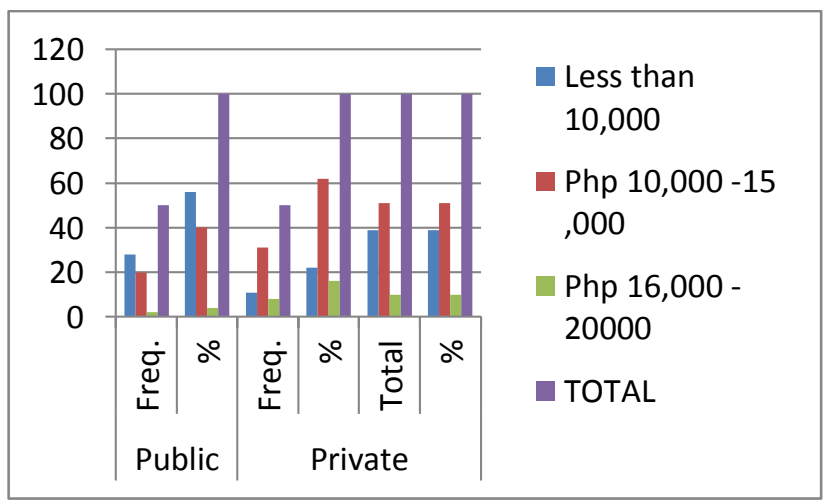

The monthly salary of 39 heads of offices from the public and private sector range from Php 10,000 - 15, 000 with the same amount earned by 62 subordinates monthly.

Table 21:- Distribution of Managers as to Rate of Promotion

\begin{tabular}{|l|l|l|l|l|l|l|}
\hline Rate of Promotion & Public & Private & \multicolumn{3}{l|}{} \\
\hline & Freq. & $\%$ & Freq. & $\%$ & Total & $\%$ \\
\hline Never & 5 & 10 & 7 & 14 & 12 & 12 \\
\hline Once & 10 & 20 & 15 & 30 & 24 & 25 \\
\hline Twice & 8 & 16 & 9 & 18 & 17 & 17 \\
\hline Thrice & 14 & 28 & 11 & 22 & 26 & 25 \\
\hline More than 3 times13 & 13 & 26 & 8 & 16 & 21 & 21 \\
\hline Total & 50 & 100 & 50 & 100 & 100 & 100 \\
\hline
\end{tabular}




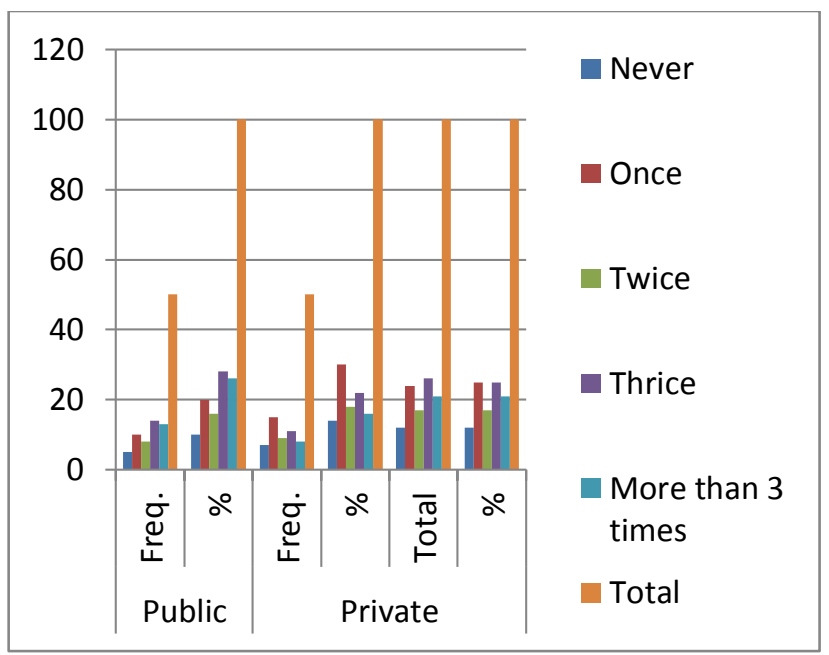

Table 22:- Distribution of Subordinates as to Rate of Promotion

\begin{tabular}{|l|l|l|l|l|l|l|}
\hline Rate of Promotion & Public & Private & \\
\hline & Freq. & $\%$ & Freq. & $\%$ & Total & $\%$ \\
\hline Never & 20 & 40 & 20 & 40 & 40 & 40 \\
\hline Once & 15 & 30 & 19 & 38 & 34 & 34 \\
\hline Twice & 5 & 10 & 3 & 6 & 8 & 8 \\
\hline Thrice & 5 & 10 & 13 & 6 & 8 & 8 \\
\hline More than 3 times13 & 5 & 10 & 5 & 10 & 10 & 0 \\
\hline Total & 50 & 100 & 50 & 100 & 100 & 100 \\
\hline
\end{tabular}

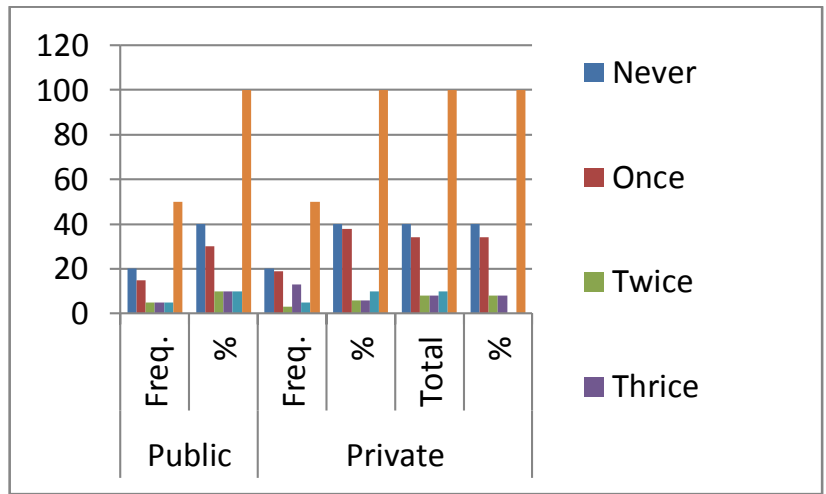

A total of thirty (30) heads of offices have been promoted once only while forty (40) subordinates from both public and private sectors have never been promoted.

\section{Level of Performance of Respondents:-}

In terms of the management functions of planning and organizing, both the public and private managers perceived themselves to be "Very Effective" with overall weighted mean values of 3.47 and 3.44, respectively. Likewise, the subordinates have perceived the level of performance of their respective managers to be "Very Effective" also with overall weighted mean values of 3.37 and 3.29 in that order.

With regard to utilization and management of resources, the public and private managers perceived the level of performance as "Very Effective" with overall weighted mean values of 3.48 and 3.44. In the same manner, the overall weighted mean value of 3.47 given by the subordinates for the performance of the managers corresponds to "Very Effective". 
The public and private managers have perceived themselves to be "Very Effective" in the performance of their function in terms of promptness in submission of reports (overall weighted mean 3.34 and 3.65). Their subordinates likewise perceived the same "Very Effective" (overall weighted means of 3.67 and 3.42)

With respect to the function of problem analysis and decision making, the public and private managers perceived their level of performance to be "Very Effective" as evidence by overall weighted means of 3.51 and 3.47. The same level of performance "Very Effective" was given by their respective subordinates with overall weighted means of 3.50 and 3.45 in that order.

In terms of the function of leadership and personnel management, both groups of managers perceived themselves to demonstrate "Very Effective" level of performance (Overall weighted means of 3.48, and 3.58). Their subordinates also perceived their managers to be "Very Effective" In their performance with overall weighted means of 3.65 and 3.63 respectively.

In terms of public relations and community involvement the public managers perceived themselves to be "Very Effective" for the reasons that managers in the public should be of service to the people, (overall weighted mean + 3.41) but private managers perceived themselves to be "Effective" only because they followed the company procedures (overall weighted mean $=3.21$ ) On the other hand, both groups of subordinates perceived their managers to be "Very Effective" in their performance (overall weighted mean $=3.38$ and 3.31)

There is a significant difference between the perceptions of public managers and their subordinates on the level of performance of the managers with respect to the function of planning and organizing and promptness in the submission of reports.

There is a significant difference between the perceptions of private managers and their subordinates on the level of performance of the managers with respect to the functions of planning and organizing and promptness in the submission of reports.

\section{Perception of Respondents on Job-Related Factors:-}

Both public and private managers perceived their time management to be "Very Adequate" with overall weighted means of 3.27 and 3.33 respectively.

With regard to the extent of adequacy of the managers' attitude towards their jobs, the public and private managers perceived that it is only "adequate" as evidence by overall weighted means of 2.93 and 3.11.

In terms of working conditions, the public managers perceived to be "Adequate" only (overall weighted mean of 3.17) while private managers perceived their working conditions to be "Very Adequate" (overall weighted mean 3.32)

Both public and private managers perceived the extent of adequacy of their relationships with subordinates to be "Very Adequate" (overall weighted means 3.62 and 334.

For public managers, the computed r-values showed highly significant relationship between level of performance and relationship with subordinates but moderately significant relationship between level of performance and time management,, attitudes towards job and working conditions.

For private managers, there is significant low relationship between the level of performance and the job-related factors in terms of time management, attitudes towards job, working conditions and relationship with subordinates.

\section{Problems Encountered by Heads of Offices:-}

The "Very Serious" problems encountered by public managers are financial constraints, lack of facilities and equipment, no pay for extra works, and defective and inefficient office procedures.

In the case of private managers, the "Very Serious" problems are financial constraints, salary not compensated to the nature of job environment not conducive for working, and labor union among employees. 


\section{Conclusion:-}

Based on the finding of the study, the following conclusions have been drawn:

The public and private managers are generally between $41-45$ years old, married females with permanent positions who have additional masteral units to their bachelors' degrees; have stayed in their jobs for more than 20 years even if they have been promoted only once and have been receiving a monthly salary between Php 10,000-15,000 with no awards received yet.

Furthermore, the public and private subordinates are generally 25-30 years old, single females who occupy permanent positions as clerks for 1-5 years and who have finished their bachelor' degree but who have not been promoted yet or received any awards but earn between Php 10,000-15,000.

There is a significant difference on the level of performance of public managers as perceived by their subordinates and the managers themselves in the function of planning and organizing.

There is also a significant difference between the level of performance of private managers as perceived by their subordinates and the managers themselves in the function of planning and organizing and promptness in the submission of reports.

Therefore, the null hypothesis that there is no significant difference between the level of performance of the managers as perceived by their subordinates and the managers themselves is accepted.

The private managers are "Very Adequate" in terms of time management, working conditions and relationship with subordinates but public managers are "Adequate" only with regards to attitude towards job and working conditions.

There is highly significant relationship between the level of performance of public managers and the job-related factors with respect to relationship with subordinates but only a significant low relationship with subordinates but only a significant low relationship between the level of performance of private managers and the job-related factors in terms of time management, attitude towards job, working conditions and relationship with subordinates.

Therefore, the null hypothesis that there is no significant relationship between level of performance of the managers and the job related factors as indicated by the time management, attitude towards job, working conditions and relationship with subordinates is totally rejected.

\section{Recommendations:-}

In view of the findings and conclusions of the study, the following recommendations are offered:

1. The public and private agencies/offices should include in their organizational set-up some priority measures on budget allocation for the professionalization of the heads of offices such as graduate studies and/or enrichment activities like in - service training/seminars/workshops.

2. Considering that there are fewer chances of promotions nowadays in both public and private offices/agencies, it would be better for ordinary employees like clerks to equip themselves with one more skills and competencies by further studies or taking up other alternative fields of specialization which could provide them with additional income and more chances of promotion.

3. Since there is a significant difference in the perceptions of managers and subordinates regarding the level of performance of the managers in exercising their management functions, the office/agency may institutionalize that could foster or promote better superior-subordinate relationship that would eventually lead to a higher level of performance from both of them.

5. An open communication system should exist in the organization, particularly between the heads of private offices/agencies and their subordinates. having transparency and clear-cut guidelines in the implementation of office procedures and policies could enhance the existence of an ideal working environment.

6. Most of the time, it could not be helped if public offices/agencies have less sufficient human and material resources than their private counterparts. In such cases, it would be a wise move for the heads of offices/agencies to be more resourceful, creative and innovative in finding ways and means of producing optimum results even with minimal resources.

7. Because of the significant relationship existing between the level of performance of heads of offices/agencies and the job- r-related factors in terms of time management, attitudes towards job, working conditions and 
relationship with subordinates, it is highly recommended that these factors be constantly monitored and improved to ensure the maintenance of an effective and productive workforce.

8. The public and private agencies should make provisions for the professionalization of the head of offices to improve the level of performance of the managers.

9. Further studies on the level of performance of heads of offices/agencies both in public and private sectors.

\section{Acknowledgement:-}

1. The author wishes to express deep appreciation to the following:

2. Dr. Lourdes P. Israel, Dean of Graduate School and Chairman of the Oral Examination Committee.

3. Dr. Aurora P. Caligagan and Dr. Belen R. Manzanero, members of the Oral Examination Committee.

4. Dr. Ernesto C. Espejo for his unselfish support and patience in extending his expertise in the completion of the study.

5. Mrs. Petra P. Bautista for the analysis of the statistical treatment used.

6. Dr. Arturo P. Parcon and Dr.Teresa Yambao for their full support to attain the challenging endeavor and for the success in the completion of this research.

7. Finally, deep appreciation to the INTERNATIONAL JOURNAL OF ADVANCED RESEARCH for accepting this researcher paper for publication.

\section{References:-}

\section{Books:-}

1. Bowditch, James L Behavior in Organizations. A system Approach to Managing. $2^{\text {nd }}$ ed. (Reading. Massachusetts: Addison - Wesley Publishing Company, Inc. 1997).

2. Cronin, Bryans P. Complex Organizations, Organization Theory. ( Mice Worris Production Inc., New York 1994).

3. Dale, Ernest B. Management Theory and Practice $3^{\text {rd }}$ ed. (New York. McGraw - Hill. 1994).

4. Dimock, Marshall E. and Dimock, Gladys O. Public Administration, rev. ed (New York: Holt Rinehart and Winston Inc. 1993

5. Donnel, Cyril O. Essentials of Management. (New York. McGraw - Hill Book Company Inc. 1997).

\section{Periodicals:-}

1. Andres, Tomas D. Management by Values. Earist Journal of Graduate and Faculty Studies . Vol Vi, No.1 (January - December 1990).

2. Andres Tomas D. Understanding Filipino Values: A Management Approach. Panorama (June 1991).

3. Bautista, C. F. Personal and Group Factors in Leaders' social Perception (Panorama 1998)

4. Barnard, Cluster I. The Function of the Executive (Campbridge, Massachusettes: Harvard University Press 1998).

5. Bennis, Warren G. The Unconcious Conspiracy: Why Leaders Can’t Lead. (New York Willey Press.)

\section{Unpublished Materials:-}

1. Adaya, Aurora V. Administrative Impact on the Effectiveness of Managers in Private Agencies of Isabela (Dissertation 1992).

2. P Belayo, R. Relationship of the Administrators Competencies to the Performance of the Faculty of De La Salle - Emilio Aguinaldo Cavite, (Master's Thesis, DLSU - EAC. 1991).

3. Breshears, R. G. Selected Characteristics and Qualifications Relating to Leader Behavior of Administrators. Dissertations (University of Mlssourl 1995).

4. Camurungan, E. D. Determinants of Professionalism of Administrators in Selected Public and Private Agencies in Metro Manila. Dissertation (Technological University of the Philippines 1996).

5. Catacutan, P. The Effectiveness of Managers in Selected Private Agencies in Metro Manila. Dissertation (Philippine Normal University 1992). 